\title{
Redes sociales y patrimonio. Una aproximación desde la historia de la difusión de los bienes culturales
}

\author{
Adrià Besó Ros | Área de Patrimonio Cultural, Universitat de València \\ URL de la contribución <www.iaph.es/revistaph/index.php/revistaph/article/view/4823>
}

La finalidad última de los bienes que integran el patrimonio cultural es su conocimiento y disfrute por parte de la sociedad que les ha atribuido unos valores que les han otorgado un carácter destacado o sobresaliente. El movimiento cultural de la llustración y la Revolución Francesa como proceso político sentaron las bases para el nacimiento del concepto de patrimonio histórico. En sus orígenes, aunque se les reconoció su carácter social, estos bienes solo estuvieron al alcance de una minoría que tenía acceso a la cultura.

El romanticismo estableció unos nuevos vínculos emocionales con el monumento, como depositario de los valores históricos sobre los que se fundamentaba el proceso de construcción de las identidades nacionales y de los estados-nación surgidos de las revoluciones burguesas. Nuevos canales de difusión contribuyeron a identificar, valorizar y dar a conocer a la sociedad el conjunto de bienes que conformaron la base de nuestro legado histórico-artístico. No cabe duda del papel que jugó la novela Nôtre Dame de Paris, escrita por Víctor Hugo en 1831. Pero sin duda, el canal de comunicación por excelencia de la nueva sociedad burguesa fue la prensa, que se utilizó para la difusión de novedades, de noticias políticas, sociales y también fue aprovechada para dar a conocer los bienes culturales. En especial, en un momento en que en España todavía no se había iniciado un inventario general del patrimonio monumental, sirvió en muchos casos para la identificación y construcción del corpus patrimonial y para generalizar el conocimiento de estos bienes. Sirvan como ejemplo las noticias publicadas en La ilustración española y americana y en otras revistas especializadas como El museo universal, cuyos textos en muchas ocasiones estaban acompañados por ilustraciones en forma de grabados y posteriormente de fotografías, que contribuyeron a propagar la imagen de los mismos. Teodoro Llorente publicó en el diario Las Provincias las crónicas del Centre Excursionista de Lo Rat Penat, donde se presentaron los monumentos, vestigios arqueológicos, paisajes y tradiciones valencianas que iban conociendo en sus salidas periódicas. También algunos escritores, conscientes del valor de difusión de la prensa, publicaron algunos ensayos que contribuyeron a revalorizar determinados conjuntos. La escritora romántica Aurore Dupín, compañera de Chopin, presentó por entregas en 1841 en la Revue des Deux Mondes su novela Un invierno en Mallorca, que recoge las impresiones y vivencias durante su estancia en la Cartuja de Valldemossa. También el célebre Gustavo Adolfo Bécquer publicó sus cartas Desde mi celda (1864) en el periódico madrileño El contemporáneo, donde dio a conocer los valores histórico-artísticos de este cenobio cisterciense y las leyendas de los habitantes de sus valles.

Las tecnologías de la información y comunicación que definen el momento histórico actual ofrecen el uso masivo de nuevos canales de comunicación digitales, a los que el patrimonio cultural no ha permanecido ajeno. Su utilización está propiciando una nueva oportunidad de ampliar la difusión social del patrimonio y un salto cuantitativo y cualitativo respecto a los medios tradicionales. En este contexto, podemos afirmar que las redes sociales son un canal necesario para propiciar el conocimiento de los bienes culturales y la gestión que se realiza de los mismos, como lo fue la prensa en el contexto de las revoluciones burguesas del siglo XIX. El receptor del mensaje en redes, a diferencia de otros medios de comunicación, puede interactuar, y su papel activo es, en buena medida, responsable de que el contenido pueda multiplicarse y obtener una mayor difusión. En este sentido, las redes posibilitan y propician la participación 
a debate Comunicación y redes sociales en instituciones culturales

| coordina Candela González Sánchez

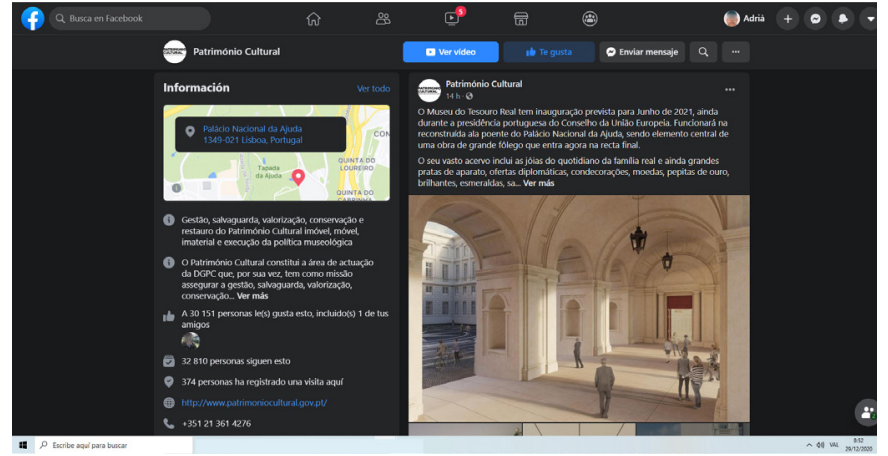

https://www.facebook.com/patrimoniocultural.pt

activa de la ciudadanía en el conocimiento y difusión de los bienes culturales en un ejercicio de corresponsabilidad en su valorización y aprecio. Por ello, cualquier institución responsable de su conservación o gestión debe servirse de las mismas para aproximar el patrimonio con una perspectiva local y también global. Estas redes se han usar en la medida que lo permitan las posibilidades de la institución, pero nunca se debe renunciar a ellas por falta de recursos o medios. Siempre es preferible hacerse presente con recursos sencillos, como una simple fotografía y algunas entradas al mes, a no estar.

Las redes sociales transmiten, además, la imagen de la institución que las crea y las gestiona. Por ello, es importante cuidar el uso que se hace de las mismas. Y en este sentido pueden resultar útiles algunas pautas básicas. Al menos, no debe faltar un sencillo manual de estilo y un plan de comunicación donde se defina cuáles son los objetivos, ejes temáticos de comunicación (presentación de obras, de publicaciones propias, comunicación de eventos, difusión de actividades de gestión, etc.) y alcance y perfiles de público al que queremos dirigirnos. En este sentido, la elección de las redes en las que queramos hacernos presentes tampoco es una decisión aleatoria, pues estará en relación con el perfil de usuarios potenciales al que queramos llegar, con la información que deseemos transmitir y con los canales que queramos o podamos utilizar.

Si durante el siglo XIX, intelectuales, eruditos y academias siempre fueron por delante en la difusión y salva-

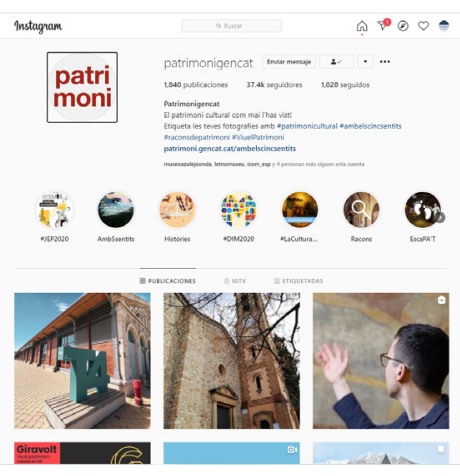

https://www.instagram.com/explore/tags/patrimonicat/?hl=es

guarda de los bienes culturales, a lo largo del siglo XX las instituciones públicas, como garantes de los intereses colectivos, han ido adquiriendo un papel cada vez más importante. Esta circunstancia explica que los perfiles de algunos museos y organismos públicos hayan obtenido un considerable número de seguidores, muy superior al de algunas cuentas de asociaciones, colectivos y particulares relacionadas con la difusión, sensibilización social de determinados bienes o categorías de bienes culturales, con un alcance nada desdeñable. La gestión amateur de estos últimos contrasta con la profesionalización de muchas instituciones, que disponen equipos de comunicación y de producción de contenidos multimedia para alimentarlas a diario. Pero tanto unas como otras son necesarias, tienen sus propias audiencias y cumplen su función social.

Como conclusión podemos afirmar que las redes sociales cumplen en el momento actual diversos fines que debe tener la comunicación para las entidades responsables de patrimonio: la difusión y conocimiento de los bienes culturales hacia la sociedad, o la dación de cuentas sobre los diversos aspectos que comprenden la gestión del legado patrimonial entendido como un bien social. Y con su carácter interactivo están abiertas a la participación de los receptores que pueden acrecentar su difusión, que sin duda revierte en un mayor conocimiento y estima hacia los mismos bienes. 